\title{
The Present and the Past of American Liberalism In Light of Slavery and Racial Injustice
}

\author{
E.G. Ponomareva
}

Moscow State Institute of International Relations (University) of the Ministry of Foreign Affairs of the Russian Federation

Book review: Gajić S. 2020. From Slave to Citizen: The Struggle of African Americans for the Recognition of Humanity. Belgrade, CATENA MUNDI. 294 р. (In Serbian) [Гајић С. Од роба до грађанина. Борба афроамериканаца за признање човечности]

Keywords: abolitionism, humanity, segregation, Frederick Douglass, W.E.B. Du Bois, Francis Bacon, blended race, double consciousness, religion, feminism.

\section{ค 7 went down in history as the year of new dividing lines and de- structive practices. The boomerang of colonial politics returned centuries later and was skillfully used for political purposes.} The BLM movement forced to revise many of the foundations of modern not only political democracy but also morality, culture, and history ${ }^{1}$. In this context, the new book by Stevan Gajic, Doctor of Political Science, a leading researcher at the Belgrade Institute for European Studies, seems exceptionally timely.

Gajićs book explores the ideas of the most influential African-American political thinkers, primarily Frederick Douglass ${ }^{2}$ and W.E.B. Du Bois ${ }^{3}$, and their relevance for

UDC: 326.4

Received: April 10, 2021

Accepted: May 15, 2021

\footnotetext{
1 Buchanan L., Quoctrung B., Patel J.K. 2020. Black Lives Matter May Be the Largest Movement in U.S. History. The New York Times. June 6. URL: https://www.nytimes.com/interactive/2020/07/03/us/george-floyd-protests-crowd-size.html (accessed 1.06.2021)

2 Frederick Douglass (1818-1895) was the most influential African-American abolitionist, political thinker, an impressive speaker, an uncompromising fighter for the cause of the abolition of slavery in the United States. Douglass himself was born in slavery. Because of this attitude, he clashed with his close friends, who were also abolitionists, who believed that free states should secede from the Union and detach from the slaveholding South. Douglass was warning them that this would be a betrayal not only of slaves and the idea of civic solidarity but also of their integrity. Douglass is also one of the most significant political figures of the American Civil War, during which he achieved great success in convincing President Abraham Lincoln to include African Americans in the army of the Union. After the war, he was the American
} 
understanding contemporary relations within American society. The book offers novel insights and comparative ideational analyses of African-American political thought from the $19^{\text {th }}$ century to the present day.

Although it captures the political thought of African Americans more broadly, the book focuses on the confrontation of the intellectual work of Frederick Douglass and William Du Bois and the dynamics in which "the second continued on the first" but "did not give identical answers." "Not only for the sake of a concrete history of political ideas, but for the sake of giving universal answers," as the author states, "which contain somewhat abstract notions such as freedom, equality, or justice" (p. 8).

Gajić analyses different views of Douglass (Douglass 1881; Douglass 1869) and Du Bois (Du Bois 2007) concerning the future of African-Americans in the country to which their ancestors were forcibly brought. Douglass, a liberal thinker, placed the individual's interest in the center of his viewpoint on the equalization of all people in their natural rights and the subsequent emancipation of African-Americans from slavery (p. 128). Du Bois, a socialist, focused on collective interests and found the position of African-Americans in society fundamentally undermined, doomed to forever measure themselves by standards they did not create and to look upon themselves through 'white' eyes. He argued this prevented them from attaining happiness, even if their position was legally equated with white America, as the psychological traces of slavery would remain. The author skillfully contrasts the basic postulates of the political philosophies of Douglass and Du Bois. The former developed a line from liberal individualism to American messianic nationalism, while the latter followed the path of socialism, an understanding of permanently disrupted collective (racial) relations in America, and the double consciousness of African Americans (p. 14). The first was a Christian, the second an agnostic. The first is an apologist for the Declaration of Independence; the second is its critic (p. 130). Throughout the book, the author occasion-

\footnotetext{
ambassador to Haiti. In the United States to this day, the word abolitionist is synonymous with the name of Frederick Douglass.

3 W.E.B. Du Bois (1868-1963) is undoubtedly one of the most influential figures in the African-American struggle for emancipation. He was also an extremely productive writer. Although, unlike Frederick Douglass, born a free man in the northern state of Massachusetts, Du Bois had early in life felt the injustice of racial segregation in the South. Segregation with which Du Bois was preoccupied for most of his professional life started after the American Civil War. The racial segregation and injustice gave him inspiration for inventing the concept of the color line, double consciousness, and other obstacles which tormented the African American people, or "The Black Folk," as Du Bois liked to call his people. Because of his political views, especially his sympathy for communism, although he enjoyed a high international reputation, Du Bois was not entirely accepted in the Pantheon of American heroes. He thoroughly resented the American establishment for its entire activity. In doing so, they provoked a unique rage campaign, as in the case of the article he wrote on the occasion of Stalin's death. Du Bois' visit to the USSR and meetings with Khrushchev and China with Mao Zedong also provoked anger back home. Du Bois founded the Niagara Movement, which opposed the then-dominant school of thought of another black leader, Booker T. Washington, and his Tuskegee ideology of compromise with racial segregation. Du Bois is the founder of the most famous organization of African Americans, the National Association for the Advancement of Colored People or NAACP. Because of the political attitudes that cost him severe persecution in America, he voluntarily emigrated to Ghana at the invitation of his friend, the president of that African country, Kwame Nkrumah. He also took the citizenship of Ghana, and after his death, his state burial was arranged, and his body still rests in the mausoleum in Accra.
} 
ally explains to us the influences that formed both thinkers. For Douglass, it was first Locke, Bacon, and Thomas Jefferson; for Du Bois it was Marx and Lenin.

The book offers a bold and intriguing perspective on how the roots of Douglass' thought do not go back only to Thomas Jefferson's Declaration of Independence and John Locke's 'Theory of Natural Law,' but that it also drew inspiration from a more distant past, from Francis Bacon's New Atlantis (Bacon 1627). The influence of Bacon's thought on Douglass is seen in the latter's belief that the US is an entirely new organism, with a unique and essentially messianic role in the world (p. 151). The book, therefore, reveals striking analogies between Bacon's New Atlantis (1627) and Douglass' speech "Our Composite Nationality" (1869) (Douglass 1869). Gajić points to the connection between Douglass' vision of the United States in the future and Bacon's fictional island of Bensalem, namely "choice, predestination and exceptionalism, assimilation of foreigners, superiority and order, development and geographical position, the decline of Europe and the rise of the United States (Bensalem)" (p. 127).

Further, analyzing Douglass' words with which he described the power of the USA to assimilate, enrich and provide happiness to people who come to the United States from all over the world, the author finds parallels with topics from New Atlantis (for example, the founding fathers are comparable to Bacon's merchants of light). Like Bensalem, the path (possible and uncertain) of the United States that Douglass advocated is to be a society based on natural law, overcoming the legacy of slavery with an outcome in harmonious and integrated equality for all.

According to the vision set out in that speech, the US will, just like Bacon's 'island of Bensalem,' by a policy of assimilation and attraction of the world's population, draw in citizens from the rest of the world, and thus constantly strengthen, because they are destined to lead the world. The author also constantly reminds us that Du Bois consistently continued in Douglass' footsteps; however, he challenged the reality of nominally granted civil rights to African Americans. Thus, the largest part of the book is dedicated to the analysis and comparison of the thoughts and ideas of these two thinkers.

Equally noteworthy is the book's analysis of connections-also previously unacknowledged-between the critical ideas of Du Bois and the Russian linguist and historian Nikolai Trubetzkoy (1890-1938). It explores the striking similarity between Du Bois' concept of double consciousness and Trubetzkoy's theory of cosmopolitanism as a globally imposed yet covert Romano-Germanic chauvinism (p. 135-150). Du Bois sees racial and ethnic determinism in American society and an unsolvable challenge of double consciousness for African Americans. He thinks that harmony between American and black identity is impossible for African Americans. In his most famous book, "Souls of The Black Folk", Du Bois writes - "An American a Negro; two souls, two thoughts, two unreconciled strivings; two warring ideals in one black body whose dogged strength alone keeps it from being torn asunder" (p. 8).

In addition to Douglass and Du Bois, this book analyses the political thought of other prominent African-American thinkers and activists (including Malcolm X and Martin Luther King Jr.) and their views on the position of African-Americans, the 
global place of the US, religion (p. 173-197) and feminism (p. 198-218). It invokes and examines the ideas of many other theorists in this context, from Aristotle and Machiavelli to Locke, Francis Yates, Alexander Dugin, Nikolai Danilevsky, and Edward Said - to name but a few.

The book also considers the future of liberalism and possible implications for liberal theory after its victory over the two competing 20th-century ideologies, fascism, and communism and the transition to post-liberalism (p. 229-237). It shows that the significance of the ideas of Douglass, Du Bois, and other African-American thinkers far exceeds the boundaries of this community and the parameters of the US. The issues they raised are unavoidable when considering any ethnically and racially diverse society, which gives their ideas a global character.

The first two chapters are devoted to their early youth and formative years. Then follows the central part of the book, the chapter "Douglass' vision of the future - New Atlantis and the concept of blended race versus Du Bois' double consciousness," which elaborates their intellectual work through nine subchapters following ideological themes (p. 70). Here we can emphasize two elements in particular. The author pays attention to the influence of Bacon's New Atlantis as an ideal-type utopia, the New World (with capital letters), on the formation of Douglass' views embodied in the speech "Our Composite Nationality." Although the author notices that Douglass does not explicitly mention Bacon anywhere, he draws a clear vertical between the two in which Thomas Jefferson, as Douglass' "favorite" father, the founder of the United States, is the primary mediator.

Gajić makes a unique contribution by noticing the coincidence of the critique of universalism with Du Bois and Trubetzkoy. Their critique was based on the understanding that universalist ideas are entirely contextual, originated in a particular historical moment and its circumstances, burdened with narrower experiences and worldviews, and as such unsuitable for transfer to other societies, different cultural identities. Gajić sees it this way: "that common idea is that" universality, "created for one racial or cultural identity, and according to the ideas and measures of that identity, cannot be grafted onto another identity without serious negative consequences for another identity. It is not possible because it is unnatural. When it is done, the result is a double consciousness [...] Both Du Bois and Trubetzkoy noticed the same phenomenon: the constant aspiration of a group that "copies" someone else's identity - voluntarily accepted or imposed - to achieve the "original," which is at hand, and the constant evasion of the desired target, like a mirage" (p. 135).

Trubetzkoy wrote in a completely different context - in Europe and about "Romano-Germanic" cosmopolitanism, which Gajić explains with a more extensive citation of Trubetzkoy's book Europe and Humanity. Gajić also notices the difference, which is primarily a difference of circumstances - African Americans do not have a tradition to which they could "return" to as they were people belonging to different ethnicities with different languages, who were rooted out of their land in Africa, forcefully brought to the United States where they mixed amongst themselves and with the whites. There- 
fore they were rooted out form their own cultures but were never accepted in the new land. As Douglass wrote in his "Oration in Memory of Abraham Lincoln" (1876), their destiny was only to become the stepchildren. So a "return" to their roots could not be the outcome of their emancipation, unlike with different European nations (Trubetzkoy mainly dealt with Russians and Romano-Germanic influences). Thus, essentially in his pessimism, Du Bois saw the only practical solution in the elvation of African Americans within American society. Elvation, preferably in a higher socioeconomic level, would be driven by Du Bois called 'the talented tenth' among African Americans. After this chapter, Gajić thematically and briefly deals with certain aspects of Douglass' and Du Bois' intellectual work in a comparative form. It seems that today Trubetzkoy's and Du Bois' ideas are more relevant than ever before. Gajić is essentially suggesting that chauvinism of the present became ontological in a certain sense. It is not racial or national allegiance that makes a person think they have the right or entitlement to discriminate against others, but a set of values that gives people, regardless of their background, the self-proclaimed a self-given right to behave arrogantly and essentially expect a type of servitude from others for this behavior.

Analyzing the phenomenon of American exceptionalism- long considered axiomatic and self-explanatory within the American elite, or at least a large part of itthe book finds its roots in Bacon's New Atlantis and Locke's Theory of Natural Law. The belief in exceptionalism and uniqueness has been manifested in US foreign policy since Theodore Roosevelt and Woodrow Wilson and has more recently been invoked by Barack Obama, the first US president of African descent.

Gajic also deals with the critique of American imperialism present in Du Bois's writings. Then there are religious themes. Gajić emphasized the importance of American Quaker missionaries in the early stages in the cause for the abolition of slavery. A whole chapter is dedicated to the relation of African American thinkers, including Martin Luther King Jr, Malcolm X, Douglass, and Du Bois, to Christianity. Many of them had similar views of Christianity as a religion being abused to subjugate African Americans (and other communities). Malcolm X was undoubtedly among more radical critics who rejected Christianity altogether and embraced Islam instead.

Both Douglass and Du Bois' saw parallels in the discrimination and marginalization of African Americans and women. The struggle for the political and social emancipation of women had many parallels with that of the African Americans. Thus the book also analyses the modern feminist movement and its relation to questions of race and gender. The work of Douglass, Du Bois, and other African-American activists and the sources of their political ideas have strongly influenced the dramatic events that shape the US and the whole of humankind to the present day. In feminism, Gajić sees a significant agreement between Douglass and Du Bois, with a root in the understanding of natural rights and personal freedom. The author reminds us of their biographical details (Douglass' vivid memories of his aunt's whipping, Du Bois's trauma of being left by his father when he was a child) and the great importance of the "black mother figure" in their upbringing and political thinking. 
The book examines the Baconian development of the human race from the men of the New Atlantis to Donna Haraway's concept of the cyborg - a new creature, which is no longer a human being, thus rendering the question of feminism obsolete (Haraway 1991). Cyborg is neither man nor woman, neither animal nor machine, and is all of that at the same time, similarly to the future man of Douglass' blended race of future Americans, who would no longer be white, black, Chinese, or of any other racial (or national) identity, but a combination of them (p. 223-224).

The penultimate chapter ("The End of Humanism") presents the author's attempt to connect Douglass' ideas about the post-racial or blended-racial America with thoroughly contemporary topics such as post-liberalism (Dugin), post-sexual cyborgs (Haraway), and archeofuturism (Faye). The last chapter deals with African Americans and the future of liberalism. In addition to the reliable use of literature, Gajić made several fresh observations, and here we primarily mean the observation of Bacon's influence on Douglass and the parallelism in the thinking of Du Bois and Trubetzkoy (p. 226).

The final part of the book offers observations-in the context of Douglass' and $\mathrm{Du}$ Bois' thought-on many contemporary movements in the US and their intertwining, with constant conflicts on values, peaking during the 2020 presidential campaign. One central message of the book is that the ideas of the past live today and influence the present in ways the actors of current events are often unaware of. More than that, the book represents a thematic novelty in science, it broadens our aspects of political philosophy, and therefore I can recommend publishers to translate this book from Serbian and publish it. Gajićs book is not only a severe scientific work but also a unique research endeavor. There are not many experts in Russia on this issue, so the book should be translated into the Russian language. It is equally essential that the work of Gajić gives rise to controversy, which is a breeding ground for the growth of the Tree of Knowledge. Therefore, I would like to wish the author new studies and polemical books.

\section{About the author:}

Elena G. Ponomareva - Dr. of Science (Political Science), Professor of Comparative Politics Department of Moscow State Institute of International Relations (University) of the Ministry of Foreign Affairs of the Russian Federation. 76 Prospect Vernadskogo, room 3026, Moscow, Russian Federation, 119454.

E-mail: nastya304@mail.ru

\section{Conflict of interest:}

The author declares absence of conflict of interest. 


\title{
Настоящее и прошлое американского либерализма в свете проблемы рабства и расовой несправедливости
}

\author{
Е.Г. Пономарева \\ DOI 10.24833/2071-8160-2021-3-78-97-103
}

Московский государственный институт международных отношений (университет) МИД России

Рецензия на книгу Гайич С. 2020. От раба к гражданину: Борьба афроамериканцев за признание человечности. Белград, CATENA MUNDI. 294 с.

Ключевые слова: аболиционизм, гуманизм, сегрегация, Фредерик Дуглас, У.Э.Б. ДюБуа, Фрэнсис Бэкон, смешанная раса, двойное сознание, религия, феминизм.

\section{O6 авторе:}

Елена Георгиевна Пономарева - доктор политических наук, профессор кафедры сравнительной политологии Московского государственного института международных отношений (университета) Министерства иностранных дел Российской Федерации. Россия, 119454, Москва, проспект Вернадского, 76, каб. 3026.

\section{Конфликт интересов:}

Автор заявляет об отсутствии конфликта интересов.

\section{References:}

Bacon F. 1627. New Atlantis. The Project Gutenberg EBook. URL: https://www.gutenberg. org/files/2434/2434-h/2434-h.htm (accessed 1.06.2021)

Douglass F. 1881. Life and Times of Frederick Douglass, Written by Himself: His Early Life as a Slave, His Escape from Bondage, and His Complete History to the Present Time. Park Publishing co., Hartford, Conn., Electronic Edition. URL: https://docsouth.unc.edu/neh/dougl92/menu. html (accessed 1.06.2021)

Douglass F. 1869. Our Composite Nationality. URL: https://teachingamericanhistory.org/ library/document/our-composite-nationality (accessed 1.06.2021)

Du Bois W.E.B. 2007. The Souls of Black Folk. 1903. Oxford-New York: Oxford University Press. 223 p.

Haraway D. 1991. Simians, Cyborgs and Women: The reinvention of nature. New York: Routledge. 287 p. 